\title{
Financial Flexibility in Highly Regulated Market: Indonesian Telecommunication Case during Tariff Pricing War
}

\author{
Y. Arief Rijanto \\ Finance Department, Prasetiya Mulya Business School, Jl. RA Kartini, Cilandak Barat Jakarta Selatan 12430
}

\begin{tabular}{|c|c|}
\hline ARTICLE INFO & A B S T R A C T \\
\hline $\begin{array}{l}\text { Keywords: } \\
\text { Financial flexibility, } \\
\text { Price war, } \\
\text { Telecommunication Regulation, } \\
\text { Real Option }\end{array}$ & $\begin{array}{l}\text { In year 2008, regulation of Indonesian telecommunicationindustries } \\
\text { changes due the tariff pricing war within Telecommunication opera- } \\
\text { tor. This regulation tie up the telecommunication operator and affect } \\
\text { operating revenue margin. The needs of financial flexibility within tele- } \\
\text { communication firm is increased.Capex, operating revenue and re- } \\
\text { investment needs to be flexible must be inline with competition and } \\
\text { change of technology. This paper goals is measuring financial flexibility } \\
\text { based on Capex, operating revenue and re-investment needs. Re-in- } \\
\text { vestment needs by Telecommunication operator can be financed with } \\
\text { or without financial flexibility. Data from year } 2007 \text { up to } 2014 \text { is selec- } \\
\text { ted to accommodate before and after changes of telecommunication } \\
\text { regulation. The regulation effect to financial flexibility of telecommu- } \\
\text { nication firm is still relevantbecause telecommunication industries by } \\
\text { nature needs larger capital to re-new the telecommunication techno- } \\
\text { logy. Real options method will be used to measure financial flexibility. }\end{array}$ \\
\hline
\end{tabular}

\section{INTRODUCTION}

The current Indonesian telecommunications policy reflected inIndonesian Government's "Blueprint of the Indonesian Government's policy on Telecommunications," by Ministry of Communications Decree No. KM 72 of 1999.There are three important changes are : (1) liberalize the sector with a competitive structure byremoving monopolistic controls, (2) increase transparency and predictability of the regulatory framework, and (3) create opportunities for national telecommunications operators partners.

Telecommunications development is influenced by country regulatory factors. The ideal regulation is expected to avoid the practice of predatory pricing and consumer protection against large companies that have excessive market power. Regulators responsible for managing an efficient level of competition. That is, the level of competition does 
Table 1. Indonesian Telecommunication operator market share in year 2009

\begin{tabular}{|c|c|c|c|}
\hline & Telkomsel & Indosat & Excelcomindo \\
\hline Launch Date & May 1995 & November 1994 & October 1996 \\
\hline $\begin{array}{l}\text { 2G Licensed frequency bandwidth } \\
\text { (GSM } 900 \text { \& 1800) }\end{array}$ & $30 \mathrm{Mhz}$ & $30 \mathrm{Mhz}$ & $15 \mathrm{Mhz}$ \\
\hline $\begin{array}{l}\text { 3G Licensed frequency bandwidth } \\
(2.1 \mathrm{GHz})\end{array}$ & $10 \mathrm{MHz}$ & $10 \mathrm{MHz}$ & $5 \mathrm{MHz}$ \\
\hline Licensed Coverage & Nationwide & Nationwide & Nationwide \\
\hline Network Coverage & Nationwide & $\begin{array}{l}\text { information } \\
\text { not available }\end{array}$ & $\begin{array}{l}\text { information } \\
\text { not available }\end{array}$ \\
\hline $\begin{array}{l}\text { Market share } \\
\text { (as of December 31, 2009) }\end{array}$ & $49.0 \%$ & $20.0 \%$ & $19.0 \%$ \\
\hline $\begin{array}{l}\text { Subscribers } \\
\text { (as of December 31, 2009) }\end{array}$ & 81.6 million & 33.1 million & 31.4 million \\
\hline
\end{tabular}

not harm the operators. And the operator can still makes investment in new technology without predatory pricing but also not harm consumers by higher price. The puzzle for regulators is how to create and manage dynamic conditions of competition between product, services and technologies that drive the telecommunications industry was growing up and stronger (Boyer, 2008).

The Indonesian Government prohibit operators from abusing a dominant position. Ministry of Communications issued Decree No. 33/2004 to preventing monopolies and unfair competition which sets forth measures to prohibit the abuse of their dominant position by network and service providers. The Decree prohibits a dominant provider from engaging in practices such as dumping, predatory pricing, cross- subsidies, compelling consumers to use such provider's services (in purpose to the exclusion of competitors) and hampering mandatory interconnection (including discrimination against specific providers). February 5,2008 , the Indonesian Government issued a regulation mandating tariff adjustments to the cost-based interconnection tariff regime.

There is a main changes of telecommunication regulation in 2004 and 2008 in Indonesia that triggering more competition within telecommunication operators. The competition started the tariff war. The existence of tariff packages offer low-cost carriers to make a number of large customers and the greater communication traffic. Telkomsel subscribers at the end of year 2008 rose $37 \%$ to 65.3 million compared to year 2007. Indosat rose $66 \%$ to 36.5 million, and XL rose $48 \%$ to 22.9 million. However, profit operators inevitably eroded. In 2008, Telkom's revenues (which contributed the majority of Telkomsel), to reach $\operatorname{Rp} 60.7$ trillion or an increase of $2.1 \%$. However, Telkom's net profit fell $17.4 \%$ to $\$ 10.6$ tribune. Indosat's revenue in 2008 also rose $13 \%$ to 16.5 billion, but net profits were down from $\mathrm{Rp} 2.04$ trillion to Rp 1.88 trillion. Revenue XL 2008, and even grew 45\%, but the operator XL loss of Rp 15 billion. On the other hand, competition between operators is beneficial to consumers. Regulators perform its function as a regulator of the level of healthy competition. Figure 1 is operator market share and subscribers in year 2009.

Performance of Indonesian telecommunications industry bounce back from its lowest point in the second quarter of 2010. According to Business Monitor International, the Subscriber will increase from 211 million in 2010 to 390 million in 2011 . However, the majority of the increase came from low value prepaid subscriber driven by competition and price wars between operators. The subs- 
criber increase is not necessarily will increase company revenue due to a decrease in average revenue per unit (ARPU - Average Revenue per Unit) and overall company revenue. Improved low-cost prepaid Subscriber is expected to continue over the next 5 years, but otherwise the company's revenue tends to fall. If the trend of competition between operators resulting in revenue decline continues, it's create a greater risk. How to measure financial flexibility under highly regulated market and the needs of re-investment with proper competition risk? Real options method based on Damodaran (2001) real option modelwill be used to measure financial flexibility and re-investment activity because of new technologies in the telecommunications industry. Real Options is one of the alternative methods of investment, especially investment opportunities that require large funds and non-refundable.

\section{Theoritical Framework}

Regulation and Competition in Telecommunication Industries

The regulatory intervention forimproving the economic efficiency should be at lower medium level while it is required to havehigh regulatory policies for the development of mobile telecommunications service (Leng, 2015). Future of competition in product and technology plays an important role in our actual or potential competition that determines the level of competition between telecommunication operators. The identity and potential competitor relatively difficult to guess due to the rapid development of technological innovations, products and customer service. In addition, telecommunications products and services should be viewed as a vector technology that produces entertainment and communication features that provides value to customers. Customer demand for products or expressing certain service that contribute to the overall connectivity, flexibility, security, dependability, accessibility, capacity and friendliness of telecommunications technologies. So, customers do not just use one product and service but individual communications portfolio. There are interdependencies between products and telecommunications services on a single individual. The number of people owning a smartphone is growing rapidly. These individuals are able to make voice calls and browse the Internet with the same mobile device use substitutes or supplements or does not affect established mobile voicecalling gains economic relevance (Gerpott, 2015). Regulators must understand the communication problem is because the portfolio impact on the welfare of its customers.

According to Boyer (2008), the role of regulators in order to regulate the telecommunication industries should be based on three principles of economic efficiency:

1. Conduit of reliable information for consumers on the pricing structure and product characteristics that had connectivity,flexibility, security, reliability, accessibility, capacity and user-friendliness.

2. As a field manager who set the level of competitive conditions that support both static efficiency and dynamic efficiency, and implement policies to indirectly control the monopoly and predatory pricing, the division based on the full cost of products and services.

3. Promoter of efficient investment program in the network construction and maintenance to ensure the integrity of global telecommunications networks, and designing pricing rules incorporate access all network access fees. Regulatory oversight of the telecommunications industry will be truly pro-competition and is an integral part of the implementation of competition policy.

If the government as a regulator wants to adopt proactive strategies to support the existence of healthy competition with the assumption that the incumbent has a dominant advantage, then the policy chosen better direct subsidies to the new entrant. For example, investment allowance or subsidy credit payments of tax paid in the future 
to get a certain portion of market share. Only new entrant with the advantages of potential technologies, products, customer or services that can compete with the incumbent who get admission telecommunications industry. Inefficient competitors are not allowed to enter. Customers will benefit from the efficiency level of healthy competition.

Gentzoglanis (2004) suggest telecom managers need to make decisions strategies to amid the increased of volatility. Strategic decisions relating to investments in new technologies to be crucial for customer satisfaction growth and demand. A decisive factor in the decision making process of investment was able to be different in case of regulatory changes and competition between operators in the telecommunications industry.

\section{Investment Decisions and Competition Risk}

Indonesian telecommunications regulatory changes in year 2006 and 2008 to encouraged competition between telecommunications operators. Alesina et al., (2005) explain that competition lowers companymarkup and as a consequence, companies must invest more to improve the company's competitive advantage. Conversely, Aghion et al., (2005) argues that in addition to lowering the value of mark-up, competition is shortening the availability of internal funds and will ultimately increase the cost of capital. The ability of any investment company will drop due to increased investment costs.

Increased competition tends to reduce investment in line with standard models of Industrial Organization. The relationship of competition and investment decisions are negative (Aghion\& Griffith, 2005; Martin, 2002). That is, the higher the level of competition, the smaller the investment can be made by the company. Then, the impact of economic conditions and political stability to investment increasingly obvious. Good economic conditions to stimulate investment. Political stability is the precondition for all investment activities (Drazen, 2000).

The source of fund for investment determine firm capital structure. And financial flexibility is the most important determinant of capital structure, flexibility can accordingly be obtained through a firm's capital structure policy (Graham \& Harvey, 2001). By preserving access to low-cost sources of external capital, firms are able to achieve aflexible capital structure, which in turn preserves financial flexibility (Byoun, 2008).

Investment opportunities analysis methods which is widely used in the telecommunications industry today is a engineering process models to estimate the forward-looking costs. According to Alleman (2002), methods of engineering economics and cost less than satisfactory because they do not accommodate uncertainty and the dynamics of the telecommunications business. While in the financial sector increasingly moves into a dynamic model that can connect the real business to the financial market.

Engineering economics basis using discounted cash flow (DCF). This method experience problems related to how to determine the appropriate discount rate. To accommodate the risk adjusted, capital asset pricing model (CAPM) model usually used to calculate cost of equity. Intuitively, the manager will raise the discount rate above those levels in order to accommodate risk using the discount rate. This method will lower the value of cash flows in subsequent periods. This process will distort the results and can give incorrect conclusions because of the certainty of cash flows based on assumptions. Method Decision tree analysis (DTA) is used to accommodate the possible outcomes and the DCF of the expected value of this tree is used for the evaluation. However, these methods cannot cope with the flexibility of management. Real options methods are considered to have the capacity for implementation of dynamic management and flexible. Alleman (2002) also emphasized the 
flexibility of real options in minimizing the risk of investment and competition.

Regulatory, market, competition and other pressures in the telecommunications industry forcing companies to develop technologies faster than competitors. Gentzoglanis (2004) emphasize that the real options method can be a useful tool for risk management in making capital investment decisions in the midst of the volatility of the telecommunications business. The existence of models and computer-based method allows the application of real options in the future better in anticipating the risk of competition.

Benaroch (2001) define the relationship of investment decisions and risks of competition is divided into three:

1. Firm-specific risk is the risk that arises because of endogenous factors of the company. This risk could be due to the uncertainty of the company meet a long-term capital-intensive investment.

2. Competition is due to risk factors in the control of competitors.

3. Market risk is due to uncertain factors thataffect every firm considering the same investment.

The competition risk had a payoff for the company. Gentzoglanis (2004) define types of risks and their effects on cost and payoff. The higher level of competition creates more impact on the payoff received by the company. So variations in corporate earnings is strongly influenced by the presence of competition. The variability of revenue, volatility and the risk of competition related to company operating revenue. Benaroch (2001) and Gentzoglanis (2004) confirms that the trend in competition, technological changes, network effects, exigencies of capital markets and unpredictable changes in regulatory policies are some of the factors making the investment decision process more dynamic rather than static. Managers need to have an options and flexibility in their decisions to invest. The uncertainties created by the lack of information. Capital investment is a risky activity and financial flexibility has a value added to manage the competition risk. Generally, lack of information, uncertainties, and irreversibility are the factors for the creation of an option as a value. So Real Option method can be used in the telecommunications industry to create values more than competitor.

\section{Real option and Investment Opportunities}

DCF method uses the assumption of the project will conform to expectations without management intervention in the process of project implementation. All the uncertainty is represented by the discount rate appropriate to the risks. DCF approach is static. It's not a flexible approach. Real option method enables the flexibility to postpone, cancel, modify according to circumstances. Real options model can be combines a Discounted Cash Flow model with real options in order to take into account the different drivers of net asset value, future rentals income and capital expenditures policy (Dubreuillea et.al. 2015). Alleman (2002) emphasized the importance of management flexibility in anticipation of regulatory changes and competition in the telecommunications industry.

Busby and Pitts (1997) reported from 72 sample that firms recognize the flexibility is determining factor in investment decisions but only $23.4 \%$ who admitted to have procedures to conduct such flexibility. Graham and Harvey, 2001 conducted a survey whose results showed DCF and NPV methods most widely used is (75\% of the 392 respondents). And only $27 \%$ indicated is not in line with the real option in the evaluation of investment decisions.

Strategic considerations relating to competition and the application of real options focus on the interaction with game theory which suggests the existence of an incentive to invest earlier than the competition (Dixit \& Pindyck, 1994; Kulatilaka \& Perotti, 1998). The timing and value of investment depends on competitive interactions 
(Lambrecht, 2004). Smit and Trigeorgis (2004) using a combination of real options and games to develop the company's investment strategy .The dynamics of investment strategy can be measured from company financial flexibility respond to competitive environment.

Real option models based on the assumptions companies have choices and can do it (choosing option). Real option is a practical option deals with "real" activities. It's based on option theory in finance. Option is a right (not obligation) to holders of options to carry out the transaction (buy or sell). Party option seller (writer) is obliged to buy or sell some shares to option holders. If the option is expressed in the form of contract between the seller and the holder of the option to transact a number of shares at a specified price at the time the contract matures. There are two types of option: Call and Put options.

Call Option is the right to buy shares. Right to buy is obtained by the holder of the call (call holder) that buy a call option on the call price (strike price) within a period and a certain stock price prior to maturity of option contracts. The call option holders of contracts will have a return or a profit if at maturity of call option, the stock price $\geq$ call price + call strike price. If the opposite occurs, the price of the stock price $\leq$ call price + call strike price, so the call contract holders will experience a loss of call option contracts. Put Option is the right to sell shares. It acquired the rights to sell of the put option holder on the deal to put at the price, duration and price of shares at the certain maturing (the strike price). The holder of a put option will break even or benefit if at the time of maturity, the price of the stock price $\leq$ put strike price - the price of the put option contract. The benefit using call or put option by investor is the option payoff.

In general, both the call option and put option, if the strike price will create a loss, the option will not be executed by the option holder. If there is such a case, the option holder will choose to ignore the option and did not execute the contents of the option contract. This can be done because the option is a right and not an obligation for the option holder. By ignoring options, losses will be minimized only to the extent the price of option contract purchased from the option writer. The application of real option in investment decision-making is a call option look like because the investment is an act of spending, just like a call option.

Damodaran (2001) argue that real option method can be used asCall option application to delay initial investment in project. Real Option Payoff in Figure 1 shows a call option with the underlying asset is an investment in the project, the strike price of the option is the investment needed to take the project; and the life of the option is the period for which the firm has rights to the project. The present value of the cash flows on this project and the expected variance in this present value Represent the value and the variance of the underlying asset.

\section{METHODS}

\section{Real Option Method}

This study developed the idea of Alleman (2002) and Gentzoglanis (2004) in telecommunications conceptual framework to modified Damodaran (2001) real option models. Alleman (2002) suggest that one of the methods are suitable for investment in telecommunications is a real option method. The method to be applied to the determination of investment, capital budgeting, strategic planning and cost model in use in telecommunications. Gentzoglanis (2004) confirm that the real options method can be used to identify the option of "option" available to risk managers in the middle of the competition. When management will take investment decisions in the area whose characteristics of high volatility, rapid technological change and have the uncertainty effect of regulation, then in such conditions, the real option to delay investment until capacity utilization allows to provide the investment is an optimal investment strategy. This method is in contrast to general belief that investment in the 


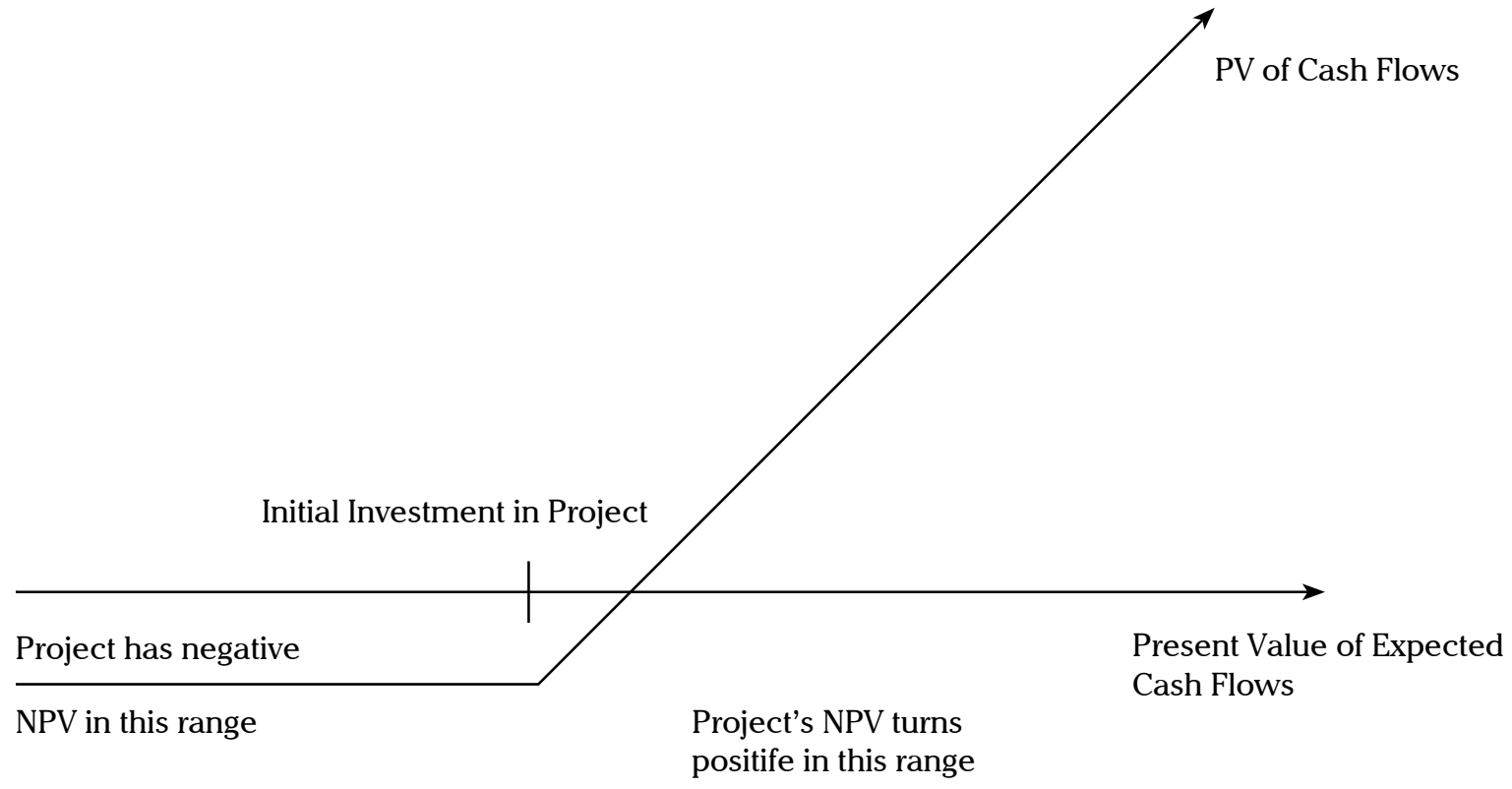

Figure 1. The Option CALL to Delay a Project (Damodaran,2001)

telecommunications industry in the capacity to be realized when the usage exceeds $50 \%$ of installed capacity.

The Black-Scholes option pricing model (BlackScholes, 1975) is used to value financial flexibility as a real option (Damodaran, 2001; Mun, 2002; Gentzoglanis, 2004). Black-Scholes model is designed to follow Europen protected by the dividend option. Executed or the possibility of dividend payments does not affect the value of call option. The value of call option in the BlackScholes model are:

$\mathrm{S}=$ Current value of the underlying asset

$\mathrm{K}=$ Strike price of the option

$\mathrm{t}=$ Life to expiration of the option

$r=$ Riskless interest rate corresponding to the life of the option

$\sigma^{2}=$ Variance in the $\ln ($ value) of the underlying asset

Black-Scholes model modified by Damodaran (2001) for the real options application is:

Value of call $=S N\left(d_{1}\right)-K e^{-r t} N\left(d_{2}\right)$ where the value of $\mathrm{d} 1$ and $\mathrm{d} 2$ :

$$
\begin{gathered}
d_{1}=\frac{\ln (s / k)+\left(r+\sigma^{2} / 2\right) t}{\sigma \sqrt{ } t} \\
d_{2}=d_{1}-\sigma \sqrt{ } t
\end{gathered}
$$

The value of a put is can be derived from the value of a call with the same strike price and the same expiration date through an arbitrage relationship that specifies that:

$$
C-P=S-K \cdot e^{-r t}
$$

Where $\mathrm{C}$ is the value of the call and $\mathrm{P}$ is the value of the put (with the same life and exercise price). This relationship can be used to value puts. Substituting the Black-Scholes formulation for the value of an equivalent call:

Value of put $=S e^{-y t}\left(N\left(d_{1}\right)-1\right)-K e^{-r t}\left(N\left(d_{2}\right)-1\right)$

where

$$
d_{1}=\frac{\ln (s / k)+\left(r-y+\sigma^{2} / 2\right) t}{\sigma \sqrt{ } t}
$$


Damodaran (2001) summary the process of valuation of options using the Black-Scholes model involves the following:

Step 1: The inputs to the Black-Scholes are used to estimate $\mathrm{d}_{1}$ and $\mathrm{d}_{2}$.

Step 2: The cumulative normal distribution functions, $\mathrm{N}\left(\mathrm{d}_{1}\right)$ and $\mathrm{N}\left(\mathrm{d}_{2}\right)$, corresponding To these standardized normal variables are estimated

Step 3: The present value of the exercise price is estimated, using the continuous timeversion of the present value formulation: Present value of exercise price $=\mathrm{K} \mathrm{e}^{\mathrm{rt}}$

Step 4: The value of the call is estimated from the Black-Scholes model.

Value of financial flexibility as an option assume that companies must have expectations of how much to invest in future periods, based on historical data of companies and competitive conditions in the industry. On the other hand, companies also have expectations of how much and which can be collected through internal funding and how the cost of access to capital markets in the future. If one assumes there is volatility in expectations in the future regarding the re-investment needs, the capacity is assumed to generate funds by the company. Profits have excess debt capacity or large cash balances are the company's ability to accommodate the needs of the investment using the company's debt capacity. Payoff of this activity is expected to come from the excess returns. Damodaran (2001) assessed the annual financial flexibility, measured by real option as Tabel 2 .

Gentzoglanis (2004) shows competition risk is against the payoff received by the company. The competition affects the company revenue. This study proposed modifications to estimate the real option approach Damodaran (2001) based on firm value with the competition risk based on changes in revenue due to competition between telecommunication operators. Therefore, this study proposed measurement methodology of real options by changing the basis of firm value in Damodaran real option model to Operating Revenue (Competition Risk Estimation Approach) as Table 3 .

\section{Financial Data and Research Samples}

This real option study is to use quarterly financial data from Indonesia Stock Exchange and Business

Table 2. Real Option Measurement (Damodaran, 2001)

\begin{tabular}{|c|c|c|}
\hline Input to Model & Measure & Estimation Approach \\
\hline $\mathrm{S}$ & $\begin{array}{l}\text { Expected Annual Reinvestment } \\
\text { Needs as \% Firm Value }\end{array}$ & $\begin{array}{l}\text { Use historical average of (Net Cap Ex }+ \text { Change in } \\
\text { Non-cash Working Capital)/ Market Value of Firm }\end{array}$ \\
\hline $\mathrm{K}$ & $\begin{array}{l}\text { Annual Reinvestment Needs } \\
\text { as percent of firm value that } \\
\text { can be raised without financing } \\
\text { flexibility }\end{array}$ & $\begin{array}{l}\text { If firm does not want to or cannot use } \\
\text { external financing: (Net Income - Dividend + } \\
\text { Depreciation) / Market Value of Firm } \\
\text { If firm uses external capital (bank debt, bonds or } \\
\text { equity) regularly: (Net Income + Depreciation + } \\
\text { Net External Financing) /Market Value of Firm }\end{array}$ \\
\hline$\sigma^{2}$ & Variance in reinvestment needs & $\begin{array}{l}\text { Variance in the expected re-investment needs as } \\
\text { percent of firm value (historical data) }\end{array}$ \\
\hline$t$ & 1 year & To get an annual estimate of the value of flexibility \\
\hline
\end{tabular}


Table 3. Real Option Measurement with Competition Risk

\begin{tabular}{cll}
\hline Input to Model & Measure & Competition Risk Estimation Approach \\
\hline $\mathrm{S}$ & $\begin{array}{l}\text { Expected Re-investment needs } \\
\text { as \% of Operating Revenue } \\
\text { with competition risk }\end{array}$ & $\begin{array}{l}\text { Use historical average of (Cap Ex + Change in } \\
\text { Non-cash Working Capital)/ Operating Revenue }\end{array}$ \\
\hline $\mathrm{K}$ & $\begin{array}{l}\text { Reinvestment Needs as } \\
\text { percent of Operting Revenue } \\
\text { that can be raised without } \\
\text { financing flexibility }\end{array}$ & $\begin{array}{l}\text { If firm does not want to or cannot use external } \\
\text { financing : } \\
\text { (Net Income - Dividend + Depreciation)/ } \\
\text { Operating Revenue }\end{array}$ \\
\hline$\sigma^{2}$ & $\begin{array}{l}\text { Variance in reinvestment needs } \\
\text { with competition risk }\end{array}$ & $\begin{array}{l}\text { Variance in the expected reinvestment as percent } \\
\text { of Operating Revenue (using historical data) }\end{array}$ \\
\hline
\end{tabular}

Monitor International reports in the period years 2007 to 2014. The research sample was chosen based on Telecommunications Company or a holding company listed on the Indonesia Stock Exchange during the years 2007-2014. There are four company; Telkomsel (TSEL), Indosat (ISAT), XL Axiata (EXCL) and Bakrie Telecom (BTEL). Company's financial data in accordance with the Damodaran (2001) methodology of real options wich is needs data : Capital Expenditure (CAPEX), Operating Revenue (OperatingRev), Capital Expenditure as percentage of Operating Revenue (CapExasOpRev) and Net profit (NetProfit).

\section{RESULTS AND DISCUSSION}

The stasistic summary of variable used for real option model as show in Table 4. Capital expenditure of four telecommunication company during year 2007-2014 is vary from -12.58 to 20650.0 that show the different investment activity. Statistic mean of Operating Revenue is less than its standard deviation, indicate that some company better than the other. And standard deviation of Net Profit is bigger than its statistic mean. We can conclude that there are a un equal competition in Indonesian the telecommunication industries during year 2007-2014.

Table 4. Summary Statistics, using the observations year 2007 -2014

\begin{tabular}{|c|c|c|c|c|}
\hline Variable & Mean & Median & Minimum & Maximum \\
\hline CAPEX & 3105.49 & 1945.29 & -12.5847 & 20650.0 \\
\hline OperatingRev & 4604.12 & 1880.00 & -556.189 & 38800.0 \\
\hline CapExasOpRev & 1.39800 & 0.674120 & -15.6692 & 56.1979 \\
\hline NetProfit & 1395.96 & 537.965 & -2150.68 & 13620.0 \\
\hline Variable & Std. Dev. & C.V. & Skewness & Ex. kurtosis \\
\hline CAPEX & 3413.46 & 1.09917 & 2.24559 & 6.22686 \\
\hline OperatingRev & 6141.63 & 1.33394 & 2.58315 & 8.99846 \\
\hline CapExasOpRev & 5.52311 & 3.95074 & 7.46492 & 74.8567 \\
\hline NetProfit & 2417.57 & 1.73183 & 2.14312 & 6.22132 \\
\hline
\end{tabular}


Damodaran (2001) real options model calculation is based on the Black Scoles model to demonstrate financial flexibility associated with the risk of competition. A proxy to capture the effects of competition based on Gentzoglanis (2004) argument that confirms the competition risk can be seen from the change in operating revenue. This study modified real option model on the estimation approach with an emphasis on Capex Operating Revenue compared intercompany to capture the effects of competition risk. Result of financial flexibility value of Telkomsel, Indosat, XL Axiata (EXCL) and Bakrie Telecom are shown in Table 5, 6 and 7.
Table 5 shows the re-investment needs that can be finance by operating revenue compared with the weighted average cost of capital (WACC) which is different at each company. Bakrie Telecom (BTEL) has the highest weighted average cost of capital. Indosat (ISAT) has the highest reinvestment requirements up to $265.17 \%$ compared to operating revenue in the years 2007 to 2014 . XL Axiata (EXCL) also requires a re-investment of about $195.62 \%$ of its operating revenue. Telkomsel (TSEL) has the lowest re-investment risk with standard deviation (std $=0.573$ ) of investment activity is relatively low compared to other operators. Bakrie Telecom needs soaring in

Table 5. Re-Investment needs as percent of Operating Revenue

\begin{tabular}{lccc}
\hline Company & $\begin{array}{c}\text { Weighted Average Cost } \\
\text { of Capital } \\
(\mathbf{2 0 0 7 - 2 0 1 4 )}\end{array}$ & $\begin{array}{c}\text { Re-investment needs } \\
\text { as percent of Operating } \\
\text { Revenue }\end{array}$ & $\begin{array}{c}\text { Standard Deviation in Re- } \\
\text { investment needs }\end{array}$ \\
\hline Telkomsel (TSEL) & $16.26 \%$ & $52.00 \%$ & 0.573 \\
\hline Bakrie Telecom (BTEL) & $25.21 \%$ & $145.21 \%$ & 1.749 \\
\hline Indosat (ISAT) & $19.99 \%$ & $265.17 \%$ & 1.174 \\
\hline XL Axiata (EXCL) & $22.86 \%$ & $195.62 \%$ & 0.832 \\
\hline
\end{tabular}

Table 6. Re-Investment with-without flexibility and value of call option for investment flexibility with Competition Risk

\begin{tabular}{lccc}
\hline Company & $\begin{array}{c}\text { Re-investment needs that } \\
\text { can be financed without } \\
\text { flexibility }\end{array}$ & $\begin{array}{c}\text { Maximum Re-investment } \\
\text { needs that can be financed } \\
\text { with flexibility }\end{array}$ & $\begin{array}{c}\text { Value of the Call } \\
\text { Option for Financial } \\
\text { Flexibility }\end{array}$ \\
\hline Telkomsel (TSEL) & $15.65 \%$ & $159.40 \%$ & 0.100 \\
\hline Bakrie Telecom (BTEL) & $0.26 \%$ & $5619.79 \%$ & -0.260 \\
\hline Indosat (ISAT) & $9.70 \%$ & $1566.92 \%$ & 0.089 \\
\hline XL Axiata (EXCL) & $33.42 \%$ & $854.89 \%$ & -0.155 \\
\hline
\end{tabular}

Table 7. Real Option Measurement with Competition Risk

\begin{tabular}{lccc}
\hline Company & $\mathbf{S}$ & $\mathbf{K}$ & $\begin{array}{c}\sigma^{2} \\
\text { (Variance) }\end{array}$ \\
\hline Telkomsel (TSEL) & $52.00 \%$ & $15.65 \%$ & 0.329 \\
\hline Bakrie Telecom (BTEL) & $145.21 \%$ & $0.26 \%$ & 3.060 \\
\hline Indosat (ISAT) & $265.17 \%$ & $9.70 \%$ & 1.379 \\
\hline XL Axiata (EXCL) & $195.62 \%$ & $33.42 \%$ & 0.692 \\
\hline
\end{tabular}


quartal to 4 in 2014, because has the lowest call option value $(-0.260)$ for financial flexibility. Indosat requires re-investment (265.17\%) and riskier with quite high standard deviation (80.25\%). Telkomsel has the lowest re-investment needs (52.00\%) and the highest call option value (0.100).

Above all of the operators, the need for re-investment and risk by Telkomsel is relatively small. It is show that Telkomsel has a stable performance of in conducting investment activities in the middle of the telecommunication operator competition during years 2007-2014. Bakrie Telecom has the highest standard deviation $(\mathrm{std}=1.749)$ and needs substantial investment (5619.79\%) needed with financial flexibility. This suggests the risk is higher if the company re-investment does not meet the needs of the re-investment target. Similarly, Indosat (ISAT) that require a large investment funds (1566.92\%) but Indosat had second best call option value (0.089) for financial flexibility.

Table 6 shows the company's financial flexibility in the years 2007-2014. Overall, the highest call option value financial flexibility is Telkomsel (TSEL) and the lowest re-investment needed (159.40\%) with financial flexibility or can be financing by company internal financing. Bakrie Telecom (BTEL) has the lowest financial flexibility, it's means that the company financing can not come from its operating revenue or internal fund but from external fund such as debt. Then, Bakrie Telecom (BTEL) and XL Axiata (EXCL) demonstrate negative call option value of financial flexibility based on operating revenue. Its shows that the financial flexibility derived from external funding, not internal.The best use of internal funds and external balance (very good) is indicated by Telkomsel.

In Table 7 , the value of $\mathrm{K}$ indicates the amount of "strike price" based on operating revenue for each carrier or telecommunication company. Telkomselas the smallest $\mathrm{K}$ value of the variance $\left(\sigma^{2}\right)=0.329$. This variance describes the variation of the value of the investment needs and financial flexibility with the risk of competition. Bakrie Telecom has the highest risk with variance (3.060). This can be a measure of risk to be faced with the need for investment in the future.

\section{CONCLUSION}

Indonesia Telecommunication regulation affect telecommunication operator operating revenue margin. With different financial flexibility within telecommunication firm, the tension of competition is increased. Re-investment needed to be survive. Some company has lower financial flexibility based on capex, operating revenue and re-investment needs will have some difficulty to compete. The regulator is expected to managing an efficient level of competition that the Telcooperator can still makes investment in new technology without predatory pricing but also not harm consumers by higher price.

Evaluation from four largest telecommunication companies in Indonesia during year 2007 to 2014, the real option method can be used as a method of measuring the risk of investment needs. Company can take advantage of investment opportunities along with increase of risk of competition. Given the "strike price", the standard deviation and variance of investment needs, Real option models have the advantage of dynamics and risk control. So that companies can use real options to manage the risk of competition related to investment opportunities. In principle, the real option method of Damodaran (2001) can be used to calculate the value of financial flexibility relating to the investment needs. Value of $S, K$ and $\sigma^{2}$ represent the components of risk with the variance in the use of capital for investment and change in operating revenue in the presence of competition. Real options can be used to measure investment needs during competition period. Manage risk investment opportunities and competition in telecommunication industries. 


\section{REFERENCES}

Alleman, J, 2002, New View of Telecommunications Economics Telecommunications Policy 26 (2002) 87-92.

Boyer, M., M. Benitah and S. Weihao, 2008. Real options, network development and network access. WIK NETCONOMICA 2008 Conference on Current Issues in Network Economics: Regulatory Risk, Cost of Capital and Investment Incentives. September, Königswinter, Germany.

Byoun, S., 2008. How and when do firms adjust their capital structures toward targets?, Journal of Finance, 63, p. 3069 - 3096.

Benaroch, M., Option-Based Management of Technology Investment Risk1, IEEE Transactions on Engineering Management, Vol. 48, No. 4, pp. 428-444, November 2001.

Damodaran, Aswath, 2001, “Corporate Finance," John Wiley \& Sons, Inc.: Hoboken.

Damodaran, Aswath, 2001,The promise and peril of real options, NYU Working Paper No. S-DRP-05-02, 2005.

Gentzoglanis, 2004. Managing Investment Risk in the Telecommunications Industry: Theory and Practice, International Telecommunication Union, Telecommunication Development Bureau, Market, Economics \& Finance Unit.

Oteroa, J., Waddams, C, 2001. Incumbent and entrant response to regulated competition: signaling with accounting costs and market prices, Journal of Economics and Business 53 (2001) 209-223.

Leng, Phirak,2015, A Cost Benefit assessment of the regulatory policy in Cambodia mobile telecommunication market, Asian Development Policy Review, (2015), (4), (1): 1-25

Graham, J. R., Harvey, C. R., 2001. The theory and practice of corporate finance: evidence from the field, Journal of Financial Economics, 61, p.187-243.

Gerpott,Meinert, 2015,The impact of mobile Internet usage on mobile voice calling behavior: A two-level analysis of residential mobile communications customers in Germany, Telecommunications Policy,Volume 40, Issue 1, February 2015, Pages $62-76$

Thamarapani, D., (2015). The Impact of Telecommunication Growth on the Service Sector: a co integration analysis. Journal of Management. 9(1), pp.58-69. DOI:

Dubreuillea, Stephane, MondherCherifb, and MondherBellalahc,(2015). "Real Options: An Alternative Valuation Model for the US REIT Market." International Journal of Business 21.1 (2015): 43. 
Appendix

Exibit 1. Real Option Model

\begin{tabular}{|c|c|c|c|c|c|c|c|c|c|c|c|c|}
\hline \multirow{2}{*}{ Company } & \multirow{2}{*}{$\mathbf{S}$} & \multirow{2}{*}{$\mathbf{K}$} & \multirow{2}{*}{$\begin{array}{c}\sigma^{2} \\
\text { (Variance) }\end{array}$} & \multicolumn{4}{|c|}{ Value of Call (lower bound) } & \multicolumn{4}{|c|}{ Value of Call (Maximum Flexibility) } & \multirow{2}{*}{$\begin{array}{l}\text { Value of the } \\
\text { Call for } \\
\text { Financial } \\
\text { Flexibility }\end{array}$} \\
\hline & & & & $d l$ & $N(d l)$ & $d 2$ & $N(d 2)$ & $d l$ & $N(d l)$ & $d 2$ & $N(d 2)$ & \\
\hline Telkomsel (TSEL) & $52.00 \%$ & $15.65 \%$ & 0.329 & 4.398 & $1.0 \mathrm{E}+00$ & 4.112 & $1.0 \mathrm{E}+00$ & -3.697 & $1.09 \mathrm{E}-04$ & -3.984 & $3.39 \mathrm{E}-05$ & $9.98 \%$ \\
\hline Bakrie Telecom (BTEL) & $145.21 \%$ & $0.26 \%$ & 3.060 & 7.670 & $1.0 \mathrm{E}+00$ & 6.796 & $1.0 \mathrm{E}+00$ & -3.721 & $9.94 \mathrm{E}-05$ & -4.595 & $2.16 \mathrm{E}-06$ & $.25 .99 \%$ \\
\hline Indosat (ISAT) & $265.17 \%$ & $9.70 \%$ & 1.379 & 5.960 & $1.0 \mathrm{E}+00$ & 5.372 & $1.0 \mathrm{E}+00$ & .2 .699 & $3.48 \mathrm{E}-03$ & -3.286 & $2.43 \mathrm{E}-01$ & $8.95 \%$ \\
\hline Excelcomindo (EXCL) & $195.62 \%$ & $33.42 \%$ & 0.692 & 4.503 & $1.0 \mathrm{E}+00$ & 4.087 & $1.0 \mathrm{E}+00$ & -3.292 & 4.97E-04 & -3.708 & $5.08 \mathrm{E}-04$ & $-4.18 \%$ \\
\hline
\end{tabular}

Exibit 2. CAPEX, Operating Revenue and Net Profit Years 2007-2014 Scatter Plot Diagram:

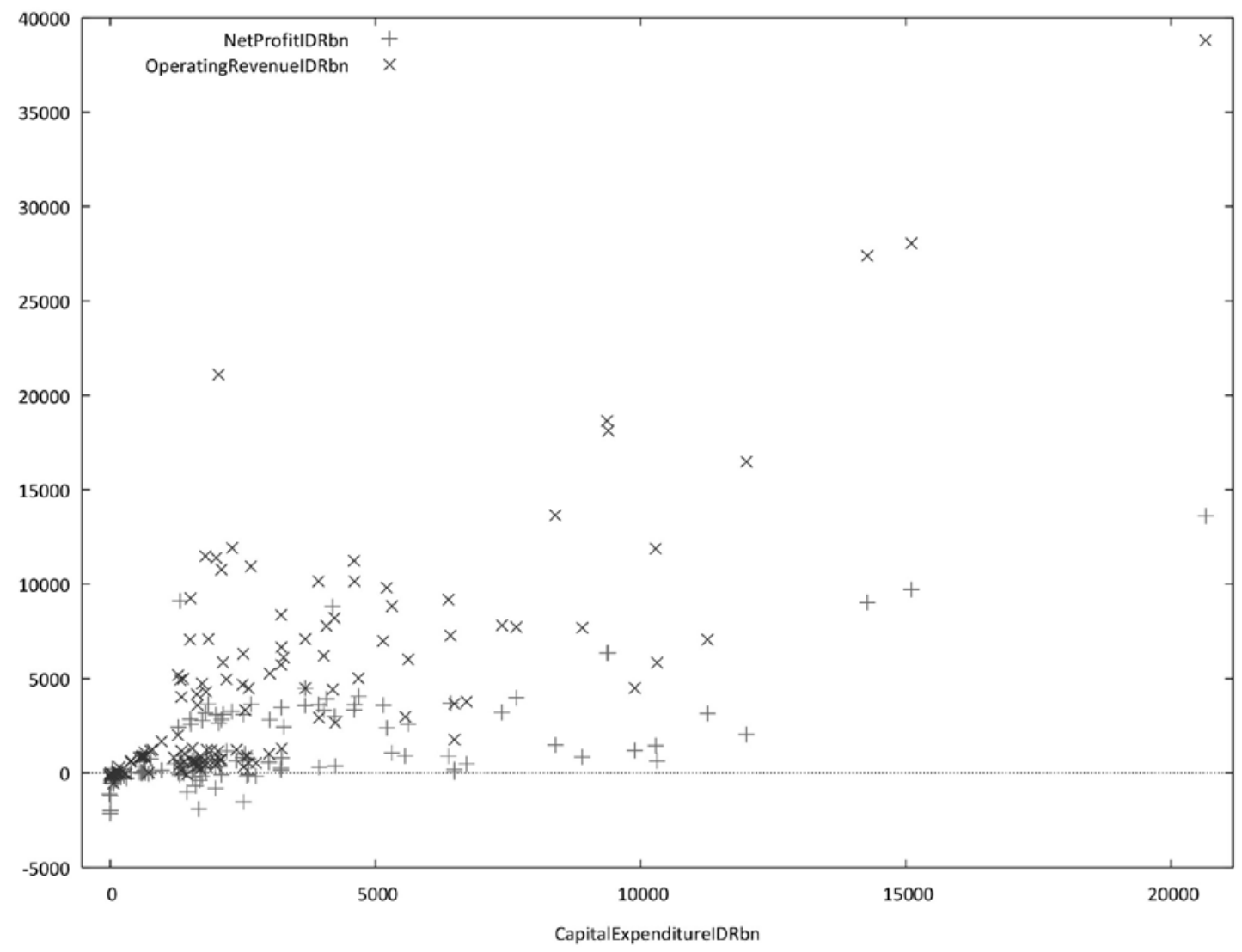

